\title{
SPECIFIC ENFORCEMENT OF ARBITRATION CONTRACTS
}

\section{Sidney P. Simpson†}

Arbitration as a method of settling disputes has a long and honorable history. ${ }^{1}$ Agreements to arbitrate existing controversies have been held valid at common law from an early date, ${ }^{2}$ as have arbitration clauses in contracts applying to disputes arising under such contracts. ${ }^{3}$ And once an award has been made pursuant to an arbitration agreement, equity will enforce it specifically if a contract between the parties in the same terms as the award would be specifically enforceable. ${ }^{4}$ Thus, an award requiring the conveyance of land will be specifically enforced, ${ }^{5}$ while one which calls merely for the payment of money will not be, because the remedy at law is adequate. ${ }^{b}$ In a suit in equity to enforce an award, discretionary defenses such as mistake, hardship,${ }^{8}$ or lack of mutuality of performance ${ }^{9}$ are available to the defendant.

Where, however, the agreement to arbitrate is still executory, different considerations arise; and the doctrine is well established that, in the absence of statute, "courts of equity will never entertain a suit to compel parties specifically to perform an agreement to submit to arbitration." 10 Clearly this doctrine does not rest on the ground that the legal remedy for the breach of an arbitration contract is adequate, since, unless the plaintiff has been put

$\dagger$ A. B., Knox College, I9I7 ; LL. B., Harvard University, I922 ; Professor of Law, Harvard Law School; member of the New York Bar; co-editor (with Zechariah Chafee, Jr.) of CASES ON EQUiTy (I934).

I. See Bentwich, Chambers of Arbitration (I893) 95 L. T. 524; CoHen, Commerctal Arbitration AND THE LAW (I9I8) 53-308; Sayre, Development of Commercial Arbitration Law (I928) 37 Y ALE L. J. 595, 596-612; The Growth of Arbitration (I929) 67 L. J. 25I. For a general account of the history of commercial arbitration law in the United States, see Jones, Historical Development of Commercial Arbitration in the United States (1928) I2 MinN. L. Rev. 240.

2. See Livingston v. Ralli, 5 E. \& B. I32 (Q. B. I855) ; Pond v. Harris, II3 Mass. II4 (I873) ; Sturges, Commercial ARbitration aNd Awards (I930) $\$ 84$.

3. But see Cocalis v. Nazlides, 308 I11. 152, 139 N. E. 95 (1923); Conant v. Arsenault, II Me. 4 II, III Atl. 378 (1920). C $f$. STURGES, op. cit. supra note 2, § 22.

4. See Hall v. Hardy, 3 P. Wms. I87 (Ch. r733); Jones v. Boston Mill Corp., 4 Pick. 507 (Mass. I827). See also Ballance v. Underhill, 4 Ill. 453,459 (I842); Bremer Oeltransport G. m. b. H. v. Drewry, [1933] I K. B. 753,758 .

5. See, e. g., Pawling v. Jackman, 5 Litt. I (Ky. I795); Boyd's Heirs v. Magruder's Heirs, 2 Rob. 76i (Va. I844); Myers v. Easterwood, 60 Tex. 107 (1883).

6. Howe v. Nickerson, I4 Allen 400 (Mass. 1867). See also Hall v. Hardy, 3 P. Wms. I87, Igo (Ch. 1733) (reporter's note); Story v. Norwich \& Worcester R. R., 24 Conn. 94, II4 (I855); Turpin v. Banton, Hardin 3I2, 313 ( $\mathrm{Ky}$. I808); Bubier v. Bubier, $24 \mathrm{Me} .42$ (1844). Compare Memphis \& Charleston R. R. v. Scruggs, 50 Miss. 284 (1874) (money award to be secured by lien on land).

7. See Ballance v. Underhill, 4 IIl. 453,459 (I852).

8. See Nickels v. Hancock, 7 DeG. M. \& G. 300, 3I4 (Ch. I855).

9. See Blackett v. Bates, L. R. I Ch. App. II7 (I865); Gervais v. Edwards, 2 Dr. \& W. 80 (Ir. I842).

Io. Selden, J., in Greason v. Keteltas, I7 N. Y. 491, 496 (1858). The leading American case is Tobey v. County of Bristol, 3 Story 800 (C. C. D. Mass. I845), one of the last decisions of Mr. Justice Story. See Red Cross Line v. Atlantic Fruit Co., 264 U. S. 109, 120 (1923); Conner v. Drake, I Ohio St. I66, I68 (1853). 
to expense by reason of the defendant's refusal to arbitrate, he can recover only nominal damages at law; ${ }^{11}$ and, although the early common law doctrine was otherwise, ${ }^{12}$ it is impossible to avoid this rule of damages by making the arbitration agreement in the form of a penal bond. ${ }^{13}$

The refusal of courts of equity specifically to enforce arbitration contracts in spite of the manifest inadequacy of the legal remedy for their breach has been rested on various grounds. It has been said that if the court were to order the defendant to name an arbitrator, it could not compel the execution of its decree $;^{1 \pm}$ that even if the appointment of arbitrators could be enforced, the arbitrators so appointed could not be compelled to act as such or to agree $;^{15}$ and that if the court were to appoint arbitrators, it would "bind the Parties contrary to their Agreement". ${ }^{16}$ None of these grounds seems sufficient. The ordinary processes of a court of equity will be adequate in the usual case to compel the defendant to appoint an arbitrator; if the arbitrator so appointed refuses to act (and to act in good faith), the court can compel the defendant to appoint another; and, moreover, there would seem to be no objection to an appointment by the court where the defendant has refused to appoint in accordance with his agreement, since it may well be said that he must be taken to have waived his right of selection. ${ }^{17}$ More substantial, perhaps, is the argument that, since lay arbitration tribunals do not have the facilities for investigation nor the knowledge of applicable legal principles which the courts possess, a court of equity should not compel a party to submit the determination of his rights to such a tribunal. ${ }^{18}$ In reply to this argument it may be said: (I) This is just what the parties have agreed to do, and, unless there exists some public policy against extrajudicial setttlement of controversies, that agreement should be respected and enforced. (2) In a considerable number of jurisdictions, general arbitration statutes now authorize compulsory process to obtain evidence in common law arbitrations, and thus eliminate the difficulty in part. ${ }^{19}$

II. Munson v. Straits of Dover S. S. Co., Ioz Fed. 926 (C. C. A. 2d, I900) ; 2 Wirliston, Contracts (I920) \$§ I7Ig, 1927. See Doleman \& Sons v. Ossett Corp., [19iz] 3 K. B. 257, 268; Aktieselskabet Korn-Og Foderstof Kompagniet v. Rederiaktiebolaget Atlanten, 250 Fed. 935, 937 (C. C. A. 2d, 1918), aff'd sub 1rom. The Atlanten, 252 U. S. 313 (I920). Cf. McCullough v. Clinch-Mitchell Construction Co., 7I F. (2d) 17 (C. C. A. 8th, 1934).

12. See Vynior's Case, 8 Co. 8Ib (K. B. I609); CoHEN, op. cit. supra note I, I48-I52.

13. See Allen v. Watson, I6 Johns. 204, 209 (N. Y. I8I9).

14. See Tobey v. County of Bristol, 3 Story 800,825 (C. C. D. Mass. I845). See also the argument for the defendant in Agar v. Macklew, 2 Sim. \& Stu. 418 (Ch. I825) (an appraisal case).

I5. See Crawshay v. Collins, I Swanst. 40 (Ch. I8I8) ; McGunn v. Havlin, 29 Mich. 476, $48 \mathrm{r}$ (I874); Pillow v. Pillow's Heirs, 3 Humph. 644, 646 (Tenn. 1842). Cf. CLark, EQUITY (I9I9) \$ 64 .

I6. Sir John Leach, V. C., in Agar v. Macklew, 2 Sim. \& Stu. 418, 425 (Ch. I825). See Tobey v. County of Bristol, 3 Story 800,825 (C. C. D. Mass. 1845).

17. But see Paris v. Grieg, I2 Hawaii 274, 281 (I899). Cf. Hayes, Specific Performance of Contracts for Arbitration or Valuation (I916) I CoRN. L. Q. 225, 236.

18. This argument is fully developed by Mr. Justice Story in Tobey v. County of Bristol, 3 Story $800,821-822$ (C. C. D. Mass. 1845).

19. See Sturges, op. cit. supra note 2 , § 153 et seq. 
The sound ground for the accepted equity doctrine that courts of chancery will not specifically enforce contracts to arbitrate is to be found in the common law character and effect of such contracts. A contract to arbitrate, although valid at common law, is "revocable". In other words, either party to the contract is regarded as having a power to break it, although rendering himself liable (in nominal damages at least) for so doing. ${ }^{20}$ This power of revocation has two important effects at law: (I) If a party "revokes" (i.e., breaks) his contract to arbitrate, even after arbitrators have been appointed, no valid award can be made. ${ }^{21}$ (2) The breach of an agreement to arbitrate cannot be pleaded as a defense to an action brought by the party who has broken ("revoked") that agreement. 22 This characteristic of "revocability" exists at common law even though the parties have expressly contracted not to revoke the agreement to arbitrate. ${ }^{23}$

The common law rule that arbitration agreements are "revocable" appears to have had its origin in a dictum of Lord Coke in Vynior's Case. ${ }^{24}$ While it is doubtful whether this dictum accurately stated the early law, ${ }^{25}$ it has been regarded as setting forth the common law rule. ${ }^{26}$ The basic reason behind the rule, and the cause of the general acceptance of the dictum in $V y n i o r ' s$ Case, appears to have been the theory that arbitration agreements, while not absolutely illegal, were opposed to public policy because they tended to oust the courts of jurisdiction, ${ }^{27}$ and so violated "the spirit of the laws creating the courts".2s It is perhaps not too much to say with the late Judge Hough, that: "A more unworthy genesis [for the rule of revocability] cannot be imagined", ${ }^{29}$ and that "it is surely a singular view of judicial sanctity which reasons that, because the Legislature has made a court, therefore everybody must go to the court". ${ }^{30}$ As an original question, it would seem, the common law courts might well have held arbitration agreements to be irrev-

20. See Sturges, op. cit. supra note $2, \S \S 15,76$.

21. See, e. g., Boston \& Lowell R. R. Corp. v. Nashua \& Lowell R. R. Corp., I39 Mass. 463,31 N. E. 75I (I885); Jones v. Harris, 59 Miss. 214 (188I). In Pennsylvania, however, even prior to the passage of the present Pennsylvania arbitration statute [PA. STAT. ANN. (Purdon, 1930) tit. 5, $\$ \$ 16 \mathrm{I}-18 \mathrm{I} ; c f$. note 78 , infra], an agreement to arbitrate was held not to be "revocable" in this sense if the arbitrators were named in the agreement. Adinolfi v. Hazlett, 242 Pa. 25, 88 Atl. 869 (I9I3).

22. See, e. g., Kill v. Hollister, I Wils. I29 (K. B. 1746) ; Haggart v. Morgan, 5 N. Y. 422 (I85I); W. H. Blodgett Co. v. Bebe Co., Igo Cal. 665, 214 Pac. 38 (I923). See Mitchell v. Harris, 2 Ves. I29a (Ch. 1793); Street v. Rigby, 6 Ves. 814 (Ch. I802). And see Thos. W. Finucane Co. v. Board of Education, I9o N. Y. 76, 83, 82 N. E. 737, 739 (1907).

23. See People ex rel. Union Ins. Co. v. Nash, I II N. Y. 310, 315, I8 N. E. 630 (I888).

24. 8 Co. 80a, 8Ib (K. B. I609). See CoHEN, op. cit. supra note I, at 84-93.

25. See CoHen, op. cit. supra note $\mathrm{x}$, I03-127.

26. For collections of cases on the validity and effect of contracts to arbitrate at common law, see Notes (I892) 15 L. R. A. 142; (I9II) 47 L. R. A. (N. s.) 337.

27. See Scott v. Avery, 5 H. L. Cas. 811,853 (1856); Insurance Co. v. Morse, 20 Wall. 445,452 (U. S. 1874) ; Hurst v. Litchfield, 39 N. Y. 377, 379 (1868). See also I StoRY, EQUTTY JURISPRUDENCE (13th ed. 1886) §670.

28. See U. S. Asphalt Refining Co. v. Trinidad Lake Petroleum, Co., 222 Fed. 1006, 1009

(S. D. N. Y. Igr5).

29. Id. at I006.

30. Id. at 1009-1010. 
ocable. But they did not, and the law has long since crystallized. One exception, it is true, has been engrafted upon the "revocability" rule. In England, if the parties to a contract containing an arbitration clause agree that compliance with this clause shall be a condition precedent to a suit on the main contract, the courts will give full effect to this agreement. ${ }^{31}$ The American courts have refused to go so far; they give effect to an agreement that arbitration shall be a condition precedent to suit if the arbitration clause relates only to the ascertainment of value or some other matter of fact, ${ }^{32}$ but not if the contemplated arbitration is to decide the entire question of liability. ${ }^{33}$ Even where effect is thus given to an arbitration clause, it is made operative only to bar a suit on the main contract without compliance with the clause; and this does not prevent either party from preventing an award either by refusing to appoint arbitrators or by revoking their authority after appointment.

In consequence of the common law rule of the revocability of arbitration contracts, a court of equity which is asked to enforce specifically an agreement to arbitrate finds itself in this position: If it grants the relief sought by the plaintiff and compels the defendant to appoint arbitrators, the defendant can render the decree nugatory forthwith by revoking the arbitrators' authority. If the equity court should enjoin such revocation of authority, it would be refusing to follow the law in a case in its concurrent jurisdiction ${ }^{34}$ and would be setting up a special equity rule as to the character and effect of arbitration agreements-a thoroughly undesirable result. ${ }^{35}$ And if the court should appoint arbitrators for the defendant, it again would be refusing to follow the law, and would, in a sense, "bind the Parties contrary to their

3r. Scott v. Avery, 5 H. L. Cas. 8II (I856); Woodall v. Pearl Assurance Co., [I9Ig] I K. B. 593. Cf. Dreyfuss \& Co. v. Atlantic Shipping \& Trading Co., 37 T. L. R. 4I7 (Ct. App. Ig2I), noted in (Ig2I) 30 YALE L. J. 862.

32. See, $e$. g., Niagara Fire Ins. Co. v. Bishop, I54 I1l. 9, 39 N. E. II02 (1894); Delaware \& Hudson Canal Co. v. Pennsylvania Coal Co., 50 N. Y. 250 (1872). A leading case is Stephenson v. Piscataqua Fire \& Marine Ins. Co., 54 Me. 55 (I866) ; cf. Fisher v. Merchants Ins. Co., $95 \mathrm{Me}$. 486, 50 Atl. 282 (I90I). See 2 Williston, Contracts (I920) $\$ \$ 1721-1722$.

33. See, e. g., Whitney v. National Masonic Accident Assn., 52 Minn. 378, 54 N. W. I84 (1893); Meacham v. Jamestown, Franklin \& Clearfield R. R., 21 I N. Y. 346, 105 N. E. 653 (1914); Tatsuuma Kisen Kabushiki Kaisha v. Prescott, 4 F. (2d) 670 (C. C. A. 9th, 1925). Cf. Burnham, Arbitration as a Condition Precedent (I897) II HARv. L. Rev. 234.

34 See Tobey v. County of Bristol, 3 Story 800,824 (C. C. D. Mass. 1845): "When the law has declared, that any agreement for an arbitration is, in its very nature, revocable, and cannot be made irrevocable by any agreement of the parties, Courts of Equity are bound to respect this interposition, and are not at liberty to decree that to be positive and absolute in its obligation, which the law declares to be conditional and countermandable." See also Sturges, op. cit. supra note 2, at 357. Cf. Ellington v. Currie, I93 N. C. 610, I37 S. E. 869 (I927); Electrical Research Products v. Vitaphone Corp., 17I Atl. 738, 749-753 (Del. Sup. Ct. 1934), rev'g Vitaphone Corp. v. Electric Research Products, I9 Del. Ch. 354, 167 Atl. 845 (1933), (I933) 47 HaRv. L. REv. I26.

35. Compare the established doctrine that equity will not grant specific performance unless there is a valid and enforceable contract at law. See Marquis of Normanby v. Duke of Devonshire, Freem. Ch. 215, 216 (1607); Crampton v. Varna Ry. Co., L. R. 7 Ch. App. 562 (1872); Hedges v. Dixon County, I50 U. S. I82, 192 (I893). Cf. 4 PoMeroy, EQUITY JurISPRUDENCE (4th ed. I9I9) §I403, n. I. 
Agreement". so Following the law, therefore, courts of equity, if they attempted specifically to enforce arbitration agreements, would be in the same position as if they were to attempt specifically to enforce any other contract which the defendant had a power immediately to terminate. The defendant could render nugatory the court's decree as soon as it was rendered; and it has long been an established doctrine of equity that specific performance will not be granted under such circumstances. ${ }^{37}$ In other words, specific performance of arbitration contracts is refused because "the court will . . . refuse to interfere in any case where, if it were to do so, one of the parties might nullify its action through the exercise of a discretion which the contract or the law invests him with". ${ }^{3 s}$ This is not to say that courts of equity, in denying specific performance of contracts to arbitrate, have not in the past been influenced by old ideas of public policy as to "ousting the jurisdiction of the courts"; but rather that, even though this ghost be laid, there is nevertheless a sound ground for the refusal of equity specifically to enforce such contracts in view of their "revocability" at law.

The real difficulty in specifically enforcing agreements to arbitrate is thus not on the equity side of the courts at all. Granted a change in the common law rule, there is nothing (except the numbing effect of precedent) to prevent equity from enforcing specific performance of arbitration agreements on the ground of inadequacy of the legal remedy for the breach thereof, subject, of course, to the exercise of the chancellor's judicial discretion in accordance with the principles applied in other specific performance cases.

The common law rule of "revocability" of arbitration agreements is so entrenched in the cases that it can be changed only by legislation; but modern legislation has gone far to change it. Moreover, that legislation in some instances has purported to impose upon the courts a mandatory duty of specifically enforcing arbitration contracts. In order to understand the present state of the law as to the specific enforcement of such contracts, an analysis of the character and an appraisal of the effect of this legislation is therefore necessary.

The earliest important legislative enactment relating to arbitration was an English statute of $1698^{39}$ which authorized the parties to an agreement

36. See note I6, supra. But cf. p. I6I, supra.

37. See, e. g., Wheeler v. Trotter, 3 Swanst. I74, n. (a) (Ch. 1737) ; Gregory v. Wilson, 9 Hare 683 (Ch. I85I) ; Brett v. East India \& London Shipping Co., 2 Hem. \& M. 404 (Ch. 1864); Hurlburt v. Kantzler, II2 Ill. 482 (1884) ; Snyder v. Greaves, 2I Atl. 29I (N. J. Ch. 1891); Restatentent, Contracts (1932) \$377. See also Andrews v. Andrews, 28 Ala. 432,443 (I856) ; Gerling v. Lain, 269 Ill. 337, 34I, 109 N. E. 972, 974 (1915) ; Alworth v, Seymour, 42 Minn. 526, 528, 44 N. W. 1030 (1890) ; New River Lbr. Co. v. Tennessee Ry., I 45 Tenn. 266, 295, 238 S. W. 867, 875 (1921). And see Express Co. v. Railroad Co., 99 U. S. I9I, 200 (1878). See also the decisions refusing specific performance of contracts to form partnerships to continue at the will of the parties, e. g., Hercy v. Birch, 9 Ves. 357 (Ch. I804); Clark v. Truitt, I83 Ill. 239, 55 N. E. 683 (I899); Buck v. Smith, 29 Mich. I I6 (I874); Wilcox v. Williams, 92 Hun 250,36 N. Y. Supp. 944 (4th Dep't 1895).

38. Cooley, J., in Rust v. Conrad, 47 Mich. 449, 455, II N. W. 265, 267 (1882).

39. 9 \& IO WM. III, c. I5 (I698). 
tc arbitrate to insert a provision therein that the award might be made a rule of any court of record on the application of either party. If made a rule of court, refusal to perform the award was punishable as a contempt. This statute did not, however, make arbitration agreements irrevocable, nor did it provide for court appointment of arbitrators. By the Common Law Amendment Act of $1833,{ }^{40}$ the authority of arbitrators when appointed was made irrevocable without leave of court; and the Common Law Procedure Act of $I 854^{41}$ authorized any court to stay proceedings brought in violation of any agreement to arbitrate existing or future disputes, ${ }^{42}$ provided for the appointment of arbitrators by the court in the event of the failure of a party to do so, the death of an arbitrator, or other specified contingencies, ${ }^{43}$ and authorized $e x$ parte arbitrations where the parties were each to appoint an arbitrator and one of them failed to do so. ${ }^{44}$ The provisions of these statutes were incorporated in the Arbitration Act, I889, ${ }^{45}$ which further provided that an arbitrator or arbitrators may, and, if the court directs, must, ${ }^{46}$ state a special case for the opinion of the court on any question of law arising in the course of the proceedings. ${ }^{47}$ Arbitration under this Act has been extensively and successfully utilized, especially in commercial cases. ${ }^{48}$

Arbitration legislation in the United States has had a somewhat different history. All but two of the states ${ }^{49}$ have had arbitration statutes from a comparatively early date; but, prior to I920, none of these statutes in terms made agreements to arbitrate future disputes irrevocable ${ }^{50}$ nor did they pro-

40. 3 \& 4 WMr. IV, c. $42, \S 39$ (1833).

4I. I7 \& I8 VICT., c. 125 (I854).

42. Id. $\$ \mathrm{I}$. As to the effect of the similar provision of the Arbitration Act, I889, 52 \& 53 VICT., c. 49, § 4, see Doleman \& Sons v. Ossett Corp., [1912] 3 K. B. 257, 266.

43. I7 \& I 8 VICT., c. I25, \$ I2 (I854).

44. Id. \& 13 .

45. 52 \& 53 Vict., c. 49 (I889), amended in I920 by the Administration of Justice ACT, I920, Io \& II GEO. V, c. 8r, \$ 16 , and during; the present year' by the ARBITRATION ACT, 1934, 24 \& 25 GEo. $V$, c. I4, in effect January I, 1935. See also Arbitration Clauses (Protocor) ACT, I924, I4 \& I5 Geo. V, c. 39, discussed in Note (I925) I59 L. T. I30; Arbitration (Foretgn Awards) Act, 1930, 20 GEo. V, c. I5. See Creswell, The Arbitration Acts, I889 to I934, (I934) 8 J. INST. ARBITRATORS (N. S.) 35.

46. 52 \& 53 VICT., c. 49 , \$ I9 (I889). See also id. \$ 7 (b). If a party to an arbitration desires to have a special case stated and the arbitrators fail or refuse to do so, he may apply to the court for an order directing the arbitrators to state a case. See RusSELI, POWER AND DUTY OF AN ARBITRATOR (12th ed. I93I) 3 I9.

47. An agreement by the parties to an arbitration that the arbitrators shall not be required to state a special case is held to be against public policy and void. Czarnikow v. Roth, Schmidt \& Co., [I922] 2 K. B. 478 . See Russex., op. cit. supra note 46, at 78-82, 316318. Cf. Phillips, Rules of Law or Laissez-Faire in Commercial Arbitration (1934) 47 HARV. L. REv. 590, 610-613.

48. See Rosenbaum, A Report of Commerctal Arbitration, Am. Jud. Soc. Bull. XII (IgI6).

49. There are no general arbitration statutes in Oklahoma and South Dakota.

50. In Illinois, a statute enacted in IgI9 [ILL. REv. STAT. (Cahill, I933) c. 10, §3], making any "submission to arbitration" irrevocable unless expressly made revocable, has been held applicable to agreements to submit existing disputes to arbitration, and constitutional as so applied. White Eagle Laundry Co. v. Slawek, 296 Ill. 240, I29 N. E. 753 (1920). But it has been held inapplicable to general agreements to arbitrate all future disputes of whatever nature which may arise between the parties to the agreement. Cocalis v. Nazlides, 308 I11. 152, I39 N. E. 95 (I923). Cf. ARIz. REV. CODE (Struckmeyer, I928) $\$ 4300$, in force since IgOI, as amended by Ariz. Laws 1929, c. 72 . 
vide for the court appointment of arbitrators if a party to an agreement in an existing dispute failed to appoint as agreed $;^{51}$ they related rather to the method of enforcing awards, and frequently provided for the judicial confirmation or setting aside thereof. ${ }^{52}$

The pioneer American statute designed effectively to enforce arbitration agreements is the New York Arbitration Law, enacted in $1920 .{ }^{53}$ It provides that agreements to arbitrate existing disputes and arbitration clauses in contracts shall be "valid, enforceable and irrevocable, save upon such grounds as exist at law or in equity for the revocation of any contract" $;^{54}$ requires the courts to stay actions brought in violation of a submission or of an arbitration clause; ${ }^{55}$ and prescribes a procedure for the enforcement of agreements to arbitrate, providing that the trial court of general jurisdiction, upon application of the party aggrieved, after due service on the other party and "upon being satisfied that the making of the contract or submission or the failure to comply therewith is not in issue, ${ }^{56}$. . . shall make an order directing the parties to proceed to arbitration in accordance with the terms of the contract or submission". 57 Provision is also made in the statute for appointment of arbitrators by the court if no method of selection is provided for in the arbitration agreement or "if a method be provided and any party . . . shall fail to avail himself of such method". ${ }^{58}$ An ill-drawn amendment to the statute, enacted in 1927 , validates ex parte arbitrations when provided for in an arbitration agreement. ${ }^{50}$ An award of arbitrators may

5I. But cf. Tex. Confplete Stat. (Ig28) $\$ 232$, providing for the court appointment of an umpire if the arbitrators appointed by the parties disagree as to the choice thereof.

52. See Sturges, op. cit. supra note 2, §§ I-6; Note (1932) 46 HARv. L. Rev. 314; Phillips, silpra note 47 , at $592-598$. Such statutes have not ordinarily been held to make arbitration agreements irrevocable by implication. In Colorado and Washington, however, general arbitration statutes have been relied upon in deciding, contrary to the common law rule, that the breach of an arbitration clause in a contract bars a suit on the contract by the party in default under the arbitration clause. Ezell v. Rocky Mountain Bean \& Elevator Co., 76 Colo. 409, 232 Pac. 680 (1925), (I925) 23 Mrch. L. Rev. 9I I THerring-Hall-Marvin Safe Co. v. Purcell Safe Co., 8I Wash. 592, I42 Pac. II53 (1914). And in Washington an award may be made although the authority of the arbitrators has been "revoked" by a party to the arbitration. State ex rel. Fancher v. Everett, I44, Wash. 592, 258 Pac. 486 (I927). Cf. Sturges, op. cit. supra note $2, \$ 76$.

53. N. Y. Cons. Laws (Cahill, I930) c. 2. See also N. Y. Crv. Practice Act (Cahill, I93I) art. 84.

54. N. Y. ARbitration Law (Ig20) § I.

55. Id. \$ 5 .

56. If "the making of the contract or submission or the default be in issue", the court "shall summarily proceed to the trial thereof", and either party may demand a jury trial. If the jury [or, inferentially, the court-cf. Phillips, The Paradox in Arbitration Law (I933) 46 HARv. L. REv. 1258, I266, note 44] finds that there was a contract for arbitration and that there is default thereunder, the court "shall make an order summarily directing the parties to proceed with the arbitration in accordance with the terms thereof". N. Y. ARBITRATION LAw (1920) \$3.

57. N. Y. ARBitration LAW (1920) §3.

58. Id. $\$ 4$.

59. Id. $\$ 4-a$, added by N. Y. Laws 1927 , c. 352 , to overcome the effect of the decision in Matter of Bullard v. Morgan H. Grace Co., 240 N. Y. 388, I48 N. E. 559 (1925). As to the construction of $\S 4-a$, see MIatter of Finsilver, Still \& Moss, Inc. v. Goldberg, Maas \& Co., Inc., 253 N. Y. 382, I7I N. E. 579 (1930), (1930) 5 ST. JoHN's L. REv. II4, rev'g 227 App. 
be vacated by the court only (I) when "procured by fraud, corruption or undue means"; (2) when there was "evident partiality or corruption in the arbitrators"; (3) when "the arbitrators have been guilty of misconduct in refusing to postpone the hearing for cause shown, or in refusing to hear evidence pertinent and material to the controversy" "or or "any other misbehavior by which the rights of the parties have been prejudiced"; or (4) when the arbitrators "have exceeded their powers" or imperfectly executed them. ${ }^{61}$ No provision is made for either voluntary or compulsory reference to the court by the arbitrators of questions of law, and awards are not reviewable for errors of law on the part of the arbitrators. ${ }^{62}$ When an award has been made, either party may apply to the court to confirm, modify or vacate it, and the court, unless vacating or modifying the award on one of the grounds specified by the statute, must confirm it and enter judgment thereon. ${ }^{63}$ The net effect of the statutory procedure, "from the application to the . . [court], and the entry of an order appointing an arbitrator [or directing the parties to proceed to arbitration], to and including the application for confirmation of the award made by the arbitrators, . . . [is] a suit for the specific performance of the contract" ${ }^{64}$ to arbitrate.

The constitutionality of the New York arbitration statute was upheld by the Court of Appeals in Matter of Berkovitz v. Arbib \& Houlberg, ${ }^{65}$ against the claims that it violated the right to trial by jury, that it abridged the constitutional jurisdiction of the courts, and that it impaired the obligation of contracts; but the construction of the statute by the New York courts has,

Div. 90, 237 N. Y. Supp. IIo (Ist Dep't 1929). The case is discussed by Havighurst in Note (I93I) 25 ILL. I. REv. 804 . Compare Curtis, $A$ Comparison of the Recent Arbitration Statutes (I927) I3 A. B. A. J. 567, 568-569. No similar provision appears in the Draft State Arbitration Act, which has been enacted in several states. See note 78 , infre. For the text of the Draft Act see STURGES, op. cit. sippra note 2, at $977-982$.

60. This codifies the common law rule that an award will be set aside if the arbitrators refuse to hear all the material evidence offered by the parties. See STuRGes, op cit. supra note $2, \S 214, \mathrm{n}$. 88. As to whether the common law rules of evidence apply in arbitration proceedings, see I Wignione, Evidence (2d ed. Ig23) $\$ 4 \mathrm{e}$; Phillips, A Practical Method for the Determination of Business Fact (I934) 82 U. of PA. L. REv. 230, 240-245.

6r. N. Y. CIv. PRACTICE ACT (Cahill, I93I) \$ 1457 . Cf. id. \$ I458, specifying the grounds on which an award may be modified or corrected.

62. See C. Itoh \& Co. v. Boyer Oil Co., I98 App. Div. 88I, 19I' N. Y. Supp. 290 (Ist Dep't I92I) ; Everett v. Brown, I20 Misc. 349, 35I, I98 N. Y. Supp. 462,464 (Sup. Ct. 1923). Cf. Liggett v. Torrington Building Co., II4 Conn. 425, I58 Atl. 6I7 (I932). See Phillips, supra note 47 , at $602-609$.

63. See N. Y. Crv. PRACtice Act (Cahill, I93I) §\$ I456-I463.

64. Manton, $J$, in Marchant v. Mead-Morrison Mfg. Co., 29 F. (2d) 40,43 (C. C. A. 2d, 1928). See also the remarks of Brandeis, J., in Red Cross Line v. Atlantic Fruit Co., 264 U.'S. IOg, II9 (I924), and of Cardozo, C. J., in Matter of Marchant v. Mead-Morrison Mfg. Co., 252 N. Y. $284,297,169$ N. E. 386, 390 (1929). Cf. the discussion of what constitutes specific performance of an arbitration contract, infra pp. I70-173.

65. 230 N. Y. 26I, 130 N. E. 288 (I92I), (I92I) 6 CORN. L. Q. 432, (I92I) I9 MICA. L. Rev. 866. See also Red Cross Line v. Atlantic Fruit Co., 264 U. S. Iog (I924), discussed in Note (I924) Io VA. L. REv. 638 (holding the New York arbitration statute applicable to maritime contracts); Marine Transit Co. v. Dreyfus, 284 U. S. 263 (I932) (upholding the United States Arbitration Act as applied to maritime contracts); Summer v. Mackay, Io N. J. Misc. 644 (Sup. Ct. I932) (upholding the New Jersey arbitration statute); Katakura \& Co. v. Vogue Silk Hosiery Co., 307 Pa. 544, I6I Atl. 529 (1932) (upholding the Pennsylvania arbitration statute). 
in the main, been restrictive. ${ }^{66}$ Thus, the statute has been held inapplicable to agreements for appraisals ${ }^{6 \tau}$ and to arbitration provisions in collective labor agreements providing for the revision of wage scales. ${ }^{68}$ Moreover, the court has been astute to find that arbitrators have exceeded or wrongfully exercised their powers. ${ }^{69}$ Thus, an arbitration clause in a contract applicable to "all disputes arising under this contract and in the performance of the work thereunder" has been held inapplicable to a dispute arising out of a breach of the contract; ${ }^{70}$ and a clause applicable to "any controversy or difference of opinion . . . as to the construction of the terms and conditions of this contract, or as to its performance" has been held not to permit the arbitrators to award consequential damages. ${ }^{71}$ Furthermore, wrongly it would seem, the provision of the statute ${ }^{72}$ that an award may be set aside for "misbehavior" of the arbitrators "by which the rights of the parties have been prejudiced" has been held applicable to a case where an arbitrator in the best of good faith made an investigation of his own to determine a question of fact as to the quality of certain merchandise, rather than relying on the conflicting testimony of witnesses called by the parties. The award in that case was set aside without inquiry as to whether it was not in fact a fair one. ${ }^{73}$

66. Cf. General Silk Importing Co. v. Gerseta Corp., 200 App. Div, 786, 790, 194 N. Y. Supp. I5, I8 (Ist Dep't 1922), aff'd without opinion, 234 N. Y. 5I3, I38 N. E. 427 (I922). No attempt is made in this paper fully to analyze the New York decisions under the statute, and only a few of the more important decisions are even referred to. For more detailed discussions, see Popkin, Judicial Construction of the New York Arbitration Law of 1920 (1926) II CorN. L. Q. 329; Fraenkel, The Nere York Arbitration Law (1932) 32 CoL. L. Rev. 623. See also Phillips, supra note 56 , at $1272-1278$.

67. Matter of Fletcher, 237 N. Y. 440 , 143 N. E. 248 (1924), (1925) 34 YALE L. J. 98, discussed in a valuable Note (1930) 43 HARv. L. REv. 809, 8II-8I3. Accord: In re Thurston, 48 F. (2d) 578 (C. C. A. 2d, I93I); Grote v. Stein, 99 Pa. Super. 556 (1930) ; Marcus v. Safeguard Ins. Co., 77 PIrrs. L. J. 741 (Pa. C. P. 1929). See also Sturges, Arbitration under the New Pennsylvania Arbitration Statute (1928) 76 U. of PA. L. REv. 345, 357-360. As to the distinction between arbitrations and appraisals, see In re Carus-Wilson and Greene, L. R. I8 Q. B. D. 7, 9, Io (I886) ; STURGES, op. cit. supra note $2, \$ \$ 7-34$. Cf. Bangor Sav. Bank v. Niagara Fire Ins. Co., 85 Me. 68, 77, 26 Atl. 99I, 993 (I892).

68. Matter of Buffalo \& Erie Ry., 250 N. Y. 275, I65 N. E. 291 (I929), (I929) 29 Cor. L. Rev. 518, (1929) 42 Harv. L. Rev. 821. Cf. Kaplan v. Bagrier, I2 D. \& C. 693 (Pa. I929). This seems wise. Most modern American arbitration statutes, including the United States Arbitration Act, are by their terms inapplicable to contracts to arbitrate labor disputes. See STURGES, op. cit. supra note 2, \$32. Cf. IAA. GEN. STAT. (Dart, 1932) \$ 405. See also Sturges, supra note 67, at 346-349. Cf. Phillips, The Function of Arbitration in the Settlement of Industrial Disputes ( 1933 ) 33 CoL. L. Rev. I366.

69. Cf. (1934) 47 HARV. L. REv. 699 .

70. See Matter of Young v. Crescent Development Co., 240 N. Y. 244, 247-248, 148 N. E. 510, 5II-5I2 (I925). See also Matter of Collishaw v. Kroeger, 2 II App. Div. 809 (I924) (repudiation of entire contract). But $c f$. Matter of General Footwear Corp. v. A. C. Lawrence Leather Co., 252 N. Y. 577, 170 N. E. I49 (1929). See Webster v. Van Allen, 217 App. Div. 219, 216 N. Y. Supp. 552 (4th Dep't 1926), (I927) 36 Yale L. J. 137, discussed in Phillips, Arbitration and Conflicts of Laws (1934) I9 CORN. L. Q. 197, 203-205; Matter of Checker Cab Mfg. Corp. v. Heller, 24I N. Y. I48, I49 N. E. 333 (I925).

7I. Matter of Marchant v. Mead-Morrison Mfg. Co., 252 N. Y. 284, I69 N. E. 386 (1929), discussed in Weidlich, $A$ Test of Compulsory Arbitration in New York (I930) 4 CONN. BAR J. 95.

72. N. Y. CIV. PRACTICE ACT (Cahill, I93I) § 1457 (3).

73. Stefano Berizzi Co. v. Krausz, 239 N. Y. 315 , I46 N. E. 436 (1925), (I925) 34 Y ALE L. J. 905. See Isaacs, Two Views of Comnercial Arbitration (1927) 40 HARV. L. Rev. 929; Phillips, supra note 60, at 230-239; STURGES, op. cit. supra note 2, \$2I7. Cf. Matter of New- 
On the other hand, the decisions that the question of whether there was fraud in the inducement of a contract containing an arbitration clause is not arbitrable ${ }^{74}$ seem entirely sound. ${ }^{75}$ Litigation as to the effect of the statute and as to the powers of arbitrators under various arbitration provisions in contracts and submissions has been extensive, and it can hardly be said that the New York experience bears out the claims of the advocates of compulsory arbitration that it is speedy, private, friendly and cheap. ${ }^{76}$ Too often the effect has been not to substitute arbitration for litigation, but to substitute arbitration and litigation for litigation alone. ${ }^{77}$

Statutes very similar to the New York Arbitration Law have been enacted by ten other states ${ }^{78}$ and by the federal government, ${ }^{79}$ and have been pressed for enactment elsewhere by the American Arbitration Association, which has prepared and urged the enactment of a Draft State Arbitration Act based on the New York model. ${ }^{80}$ A somewhat different type of arbitration statute has been recommended by the Conference of Commissioners

burger v. Rose, 228 App. Div. 526, 529, 240 N. Y. Supp. 436, 438 (Ist Dep't I930), aff'd without opinion, 254 N. Y. 546 , I73 N. E. 859 (I930).

In Stefano Berizzi Co. v. Krausz, supra, Cardozo, J., said (p. 3I9): "The new policy [of enforcing arbitration agreements] does not mean that there is to be an inquisition rather than a trial, and that evidence unknown to the parties and gathered, without notice may be made the basis of the judgment". And again (p. 320): "What was contemplated [by the parties and by the arbitration statute] was a hearing. What ensued was a default". "Might not the learned judge better have said (and would not a scientist or an intelligent business man -indeed, anyone other than a lawyer, and a common law lawyer at that-have said) : "The new policy means that there is to be an impartial searching after the truth by the arbitrator, who is authorized to make any investigations for this purpose that a scientist or an intelligent business man would make, rather than that there must be a formal 'trial' or 'hearing'. What was contemplated by the parties and by the arbitration statute was an untrammelled investigation to ascertain the truth of the matter in controversy, and that is just the sort of investigation which the arbitrator made". With all respect, it would seem that the court's talk of "inquisition" and "default" must be put down to the apparently instinctive prejudice of the common law judge and lawyer against methods of ascertaining facts other than the method of a trial in court or something substantially like it.

74. Matter of Cheney Bros. v. Joroco Dresses, 218 App. Div. 652, 219 N. Y. Supp. 96 (Ig26), rev'd on another ground, 245 N. Y. 375,157 N. E. 272 (I927); Matter of Ermolieff v. Liss, 140 Misc. 214, 250 N. Y. Supp. 235 (Sup. Ct. I93I). See also Goldberg v. Mackay, I07 N. J. L. 4I2, I53 Atl. 639 (I93I). Cf. Arbitration ACr, I934, 24 \& 25 GEo. V, c. I4, \$ $14(2)$.

75. See Phillips, supra note 56, at 1270-1272. But cf. Parsell, Arbitration of Frand in the Inducentent of a Contract (I927) I2 CoRN. L. Q. 35I; [Sturges] Note (I927) 36 Y ALE L. J. 866.

76. See Phillips, supra note 56 , passim (especially at 1279).

77. See Isaacs, Book Review (1930) 40 YALE L. J. I49; Poor, Arbitration under the Federal Stattute (1927) 36 YALE L. J. 667, 669-670.

78. Cal. Code Civ. Proc. (Deering, I93I) \$§ I280-1293, enacted in 1927; ConN. GEN. STAT. (1930) c. 302, enacted in 1929; LA. GEN. STAT. (Dart, I932) $\$ \S 405-420$, enacted in Ig28; N. H. Laws I929, c. I47; N. J. Comp. STAT. (Supp. 1924) \$\$ 9-2I to 9-36, enacted in I923; O Hio Gen. CoDE ANN. (Baldwin, Supp. I932) §§ I2148-I to 12148-xg, enacted in I93I;

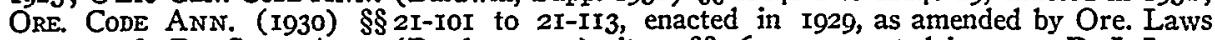
I93I, c. 36; PA. STAT. ANN. (Purdon, I930) tit. 5, §§ I6I-I79, enacted in I927; R. I. Laws I929, c. I408; WIS. STAT. (IIth ed. I93I) c. 298, enacted in I93I.

79. 43 STAT. 883 (1925), 9 U. S. C. A. $\$ \S$ I-I5 (1927). See Marine Transit Co. v. Dreyfus, 284 U. S. 263 (1932); The United States Arbitration Act and Its Application (I925) II A. B. A. J. I53; Note (I925) 25 CoL. L. REv. 822; Cohen and Dayton, The New Federal Arbitration Law (I926) I2 VA. L. Rev. 265; Note (I926) 4 HARv. BUS. Rev. 236; Poor, supra note 77; Baum and Pressman, The Enforcement of Commercial Arbitration Agreements in the Federal Courts (I93I) 8 N. Y. U. L. Q. REv. 428-445.

80. For the text of the Draft Act, see STURGES, op. cit. supra note 2, 977-982. 
on Uniform State Laws and approved by the American Bar Association. ${ }^{81}$ The Uniform Arbitration Act ${ }^{82}$ so recommended has been adopted in four states. $^{83}$ It differs from the New York statute and the Draft Act in three important respects: (I) It applies only to agreements to arbitrate existing disputes. (2) It does not provide for court orders directing the parties to an agreement to arbitrate "to proceed to arbitration in accordance with the terms of the agreement" ; but it does provide for court appointment of arbitrators where one party to a submission does not do so or where an arbitrator fails or is unable to act, and, as under the New York act, arbitrators may under certain circumstances act ex parte. (3) It provides for voluntary reference of questions of law to the court at the option of the arbitrators and for compulsory reference at the request of a party, resembling in this respect the English Arbitration Act. ${ }^{84}$ Finally, Massachusetts has a statute which applies to arbitration clauses in contracts as well as to submissions and which provides for reference to the court of questions of law, but which does not provide for orders directing arbitration, although authorizing court appointment of arbitrators to a limited extent..$^{85}$ Experience with compulsory arbitrations in Massachusetts and in the states which have adopted the Uniform Act is not yet sufficient to make possible a satisfactory study of the relative merits in practice of these types of arbitration statutes as compared with each other and with the New York and Draft Act type.

May it be said that these various statutes provide, within their respective limitations, for the specific performance of contracts to arbitrate? So far as the statutes of the New York and Draft Act type are concerned, it would seem at first glance that the answer was obviously in the affirmative. These statutes provide expressly for court orders requiring the parties "to proceed to arbitration in accordance with their agreement". Is not this decreeing direct specific performance? Clearly yes, if compliance with such an order

81. See Sturges, Arbitration under the New North Carolina Arbitration Statute-The Uniform Arbitration Act (1928) 6 N. C. L. REv. 363-377. The debate in the American Bar Association as to whether to approve the proposed Uniform Act, after having successfully pressed for the passage of the very different United States Arbitration Act, is reported in (1925) II A. B. A. J. 612-614. Compare the criticism of the Uniform Arbitration Act by the Association's Committee on Commerce Trade and Commercial Law in its report entitled The United States Arbitration Act and Its Application, supra note 79. See also Sayre, Development of Commercial Arbitration Law (1928) 37 YaLE L. J. 595, 616-617.

82. For the text of the Uniform Act, see Sturges, op. cit. supra note 2, 983-987.

83. Nev. Comp. Laws (Hillyer, I929) $\$ \$ 510-534$, enacted in 1925; N. C. Code ANN. (Michie, I93I) art 43-A, enacted in I927; UTAF IREV. STAT. ANN. (r933) c. 36, enacted in I927; Wyo. Rev. Stat. AnN. (I93I) c. 7, enacted in I927. Cf. Ill. Rev. Stat. (Cahill, 1933) c. 10, enacted in I917; note 50, stupra.

84. $C f$. the limited provisions for references to the court of matters of law in the statutes of two of the states which in the main follow the New York and Draft Acts. ConN. GeN. Stat. (I930) § 5847; Pa. Stat. AnN. (Purdon, 1930) tit. 5, § 177.

85. MASs. Gen. LAws (Ter. ed. I932) c. 25I. (Sections I2 to 22 , relating to arbitration clauses in contracts, were added in I925). See Grinnell, The Function of the Superior Court in Regard to Awards under the Massachusetts Commercial Arbitration Act of 1925 (I926) II Mass. L. Q., No. 5,4 . 
may be compelled by imprisonment for contempt, sequestration, and such other means as are available to enforce decrees for specific performance in other types of cases. On the other hand, if the only sanction behind such an order is the court's power to appoint arbitrators if a party fails or refuses to do so, the question of whether these statutes provide for the specific performance of arbitration contracts is the same as that which arises under the English and Uniform Arbitration Act type of statute, presently to be considered. On the authorities, it is an open question whether or not an order to proceed to arbitration under the New York and Draft Act type of statute is enforceable, by contempt proceedings or otherwise, directly against the party in default. No judicial decision or pronouncement on the point appears to exist, nor does the question appear to have been discussed by legal writers.

It may first be noted that both the New York and the Draft Acts are silent as to how an order "directing that. . - arbitration proceed in the manner provided for in . . . [the] agreement" to arbitrate, or "directing the parties to proceed to arbitration in accordance with the terms of the agreement" 86 is to be enforced, except for the provision that "if a method [of naming or appointing an arbitrator or umpire] be provided [in the arbitration agreement] and any party thereto shall fail to avail himself of such method . . . then upon the application of either party . . . the court . . . shall designate and appoint an arbitrator or arbitrators or umpire, as the case may require". 87 This mode of enforcement by court appointment of arbitrators seems clearly enough available if a party fails or refuses to comply with an order directing him "to proceed to arbitration"; is it the only method of enforcing such an order? On the one hand, it may be urged that the legislature has set up a self-contained statutory scheme for the enforcement of arbitration agreements; that an ample statutory sanction is made available; and that courts should not, without clear legislative authority and direction, take it upon themselves to supply a sanction other than that which the legislature has expressly provided, especially when that additional sanction involves the possibility of imprisonment of the defendant under circumstances where such imprisonment would not have been ordered under classical equity practice and has not been directly authorized by statute. On the other hand, it may be argued that the legislature has declared a policy in favor of the enforcement of arbitration agreements, which the courts should endeavor to effectuate by all appropriate means at their disposal; that what the legislature has really provided for by the statutory procedure is "a suit for the spe-

86. N. Y. Arbitration Law (i920) § 3; Draft State Arbitration Act § 3. The same provisions appear in the United States Apbitration ACT $\$ 4,43$ Stat. 883 (Ig25), 9 U. S. C. A. $\$ 4$ (Ig27).

87. N. Y. Arbitration Law (1920) §4; Draft State Arbitration Acr §4. The same provision appears in the UnITED States ARBitration ACT $\$ 5,43$ Star. 883 (I925), 9 U. S. C. A. $\$ 4$ (1927). 
cific performance of ... [any] contract" 88 to arbitrate, in which the ordinary sanctions for the enforcement of decrees of specific performance may be employed; and that, without express legislative authority, enforcement by contempt proceedings and other appropriate equitable means is proper whenever a new sort of equitable decree is authorized, unless some statutory or constitutional prohibition ${ }^{89}$ interferes. The opinion may be ventured that the former argument may well prove the more persuasive, especially in view of the circumstance that the statutes under discussion provide for mandatory rather than discretionary specific enforcement of arbitration agreements, ${ }^{90}$ so that the courts may well say: "Since the legislature requires us specifically to enforce all valid contracts to arbitrate, we will do so; but we will do so only by the means which the legislature itself has provided for such enforcement. Only if we are allowed to exercise our jurisdiction in our accustomed way, will we apply our own remedies". ${ }^{11}$

The English Arbitration Act and the Uniform Arbitration Act do not authorize orders directing arbitration, but do authorize the court appointment of arbitrators; and, for the reasons just outlined, it may well be that the New York and Draft Acts will be held not to be substantially different in practical effect. Can such a procedure, under which the court cannot make and enforce orders directly compelling recalcitrant parties to arbitrate, but can bring about arbitrations binding upon recalcitrant parties by appointing arbitrators for them, properly be regarded as involving the specific performance of arbitration contracts? There have been suggestions that it cannot; ${ }^{22}$ but this seems too narrow a view. To be sure, to enforce a contract to arbitrate by appointing an arbitrator for the party in default is specific enforcement cy pres rather than direct specific enforcement; but this involves nothing unusual. Such cy pres enforcement is no less specific performance than is enforcement of a contract to convey land by a decree operating in rem either directly or through a master's deed, ${ }^{93}$ or enforcement

88. Cf. note 64, supra. See also N. Y. Arbitration LAw (Ig20) §2, providing that a contract to arbitrate "shall be valid, enforcible and irrevocable, save upon such grounds as exist at law or in equity for the revocation of any contract". The same provision is contained in the UNITED STATES ARBitration Act $\$ 2,43$ STAt. 883 (I925), 9 U. S. C. A. $\$ 2$ (I927), and in the Draft State Arbitration ACt $\$ 2$.

89. Such, e.g., as one forbidding imprisonment for debt. See People ex rel. Sarlay v. Pope, 230 App. Div. 649, 246 N. Y. Supp. 4I4 (I930) ; Note (I933) 3I MICH. L. REv. 73I. No difficulty of this sort wotld appear to arise in connection with the enforcement of decrees compelling arbitration.

90. Cf. note 99 , infra.

9I. As to the desirability of providing for discretionary rather than mandatory specific performance of arbitration agreements, see pp. 174-175, infra.

92. See, e. g., Fletcher Moulton, L. J., in Dolman \& Sons v. Ossett Corp., [19ra] 3 K. B. 257, at 268; Sturges, op. cit. supra note 8I, at 392-393. But cf. STURGES, supra note 2, § I47.

93. See Note on Legislation Extending the Power of Equity to Transfer Property, I ChAFEE AND Simpson, CASES on EQUiTy (1934) 70-76; Garfein v. McInnis, 248 N. Y. 26I, 162 N. E. 73 (1928). As to decrees in rem in the absence of statutory authority therefor, see Tennant's Heirs v. Fretts, 67 W. Va. 569, 68 S. E. 387 (IgIo); Bush v. Aldrich, I Io S. C. 49I, 96 S. E. 922 (I9I8); but cf. Silver Camp Mining Co. v. Dickert, 3 I Mont. 488, 78 Pac. 967 (1904). 
of a construction contract by authorizing the plaintiff to do the work at the defendant's expense, ${ }^{94}$ or enforcement of a contract requiring continuous performance by appointing a receiver to carry out the contract. ${ }^{95}$ It may fairly be said, therefore, that the English Arbitration Act and the American statutes of the Uniform Arbitration Act type as well as those of the New York and Draft Act type (however the latter may be construed), do provide for the specific performance of such arbitration agreements as fall within their respective purviews.

Statutory specific enforcement of arbitration contracts in England has proved tolerably satisfactory, but (although experience in this country with compelled arbitration is not yet sufficient for a final judgment) this can hardly be said to have been true in the United States. ${ }^{96}$ Much of the difficulty in this country appears to have arisen from two causes: (I) Parties and their counsel have frequently failed to realize that, while arbitration is an excellent means of settling disputes as to relatively simple questions of fact, it may well be quite unsatisfactory as a method of deciding questions of ultimate liability involving complex legal relations. An ideal case for arbitration is one involving, say, the question whether certain goods are of sample quality, or are merchantable. Here the business-man arbitrator, expert in his trade, can decide far better than judge or judge and jury, especially if he is not limited to hearing witnesses in arriving at his conclusions. On the other hand, to submit to arbitration a question of ultimate liability involving complex questions of law will usually result in a compromise decision, based on rather naive general ideas of "fairness", which is "but rusticum judicium". 97 This difficulty may be eliminated, for the most part, by careful drafting and intelligent limitation of arbitration clauses in contracts ${ }^{98}$ and by the submission to arbitration of only such existing disputes as are suitable for arbitral decision. Moreover, the difficulty is less serious in those jurisdictions which provide for reference to the courts of questions of law arising in the course of an arbitration. (2) Modern American arbitration statutes have been regarded

94. See Village of Larchmont v. Larchmont Park, 185 App. Div. 330, I73 N. Y. Supp. 32 (I9I8), and the discussion of that case in Pound, Progress of the Laze, rgr8-rorg-Equity (I920) 33 HARv. L. Rev. 420, 436. Cf. FEDeral EQUITY Rule 8, 28 U. S. C. A. I2 (I927). As to when construction contracts are specifically enforceable, see Brummel v. Clifton Realty Co., I46 Md. 56, 125 Atl. 905 (1924); Zygmunt v. Avenue Realty Co., I08 N. J. Eq. 462, I55 Atl. 544 (I93I). Cf. Tennessee Electric Power Co. v. White County, 52 F. (2d) 1065 (C. C. A. 6th, I93I).

95. See Schmidtz v. Louisville \& Nashville R. R., ror Ky. 44I, 484, 4I S. W. I015, I027I028 (I897) ; Kearns-Gorsuch Bottle Co. v. Hartford-Fairmont Co., I F. (2d) 3I8, 320 (S. D. N. Y. Ig2I). As to when contracts requiring continuous performance are specifically enforceable, see Notes (I925) 25 CoL. L. REv. 348; (1927) 5 TEx. L. REv. 203.

96. Cf. notes 76,77 , supra. But cf. Grossman, Trade Security under Arbitration Lazes (1926) 35 YALE L. J. 308; Baum and Pressman, supra note 79, at 246-253.

97. Story, J., in Tobey v. County of Bristol, 3 Story 800 (C. C. D. Mass. 1845), cited note I0, supra, at 822. See the penetrating discussion in Stone, The Scope and Limitations of Commercial Arbitration (Ig24) Io Proc. ACAD. POL. SCT. 50r.

98. Cf. Year Book, Assn. of the Bar of the City of New York 1925, 275-276. 
as imposing upon the courts a mandatory "duty to enforce" ${ }^{90}$ arbitration agreements. The English Arbitration Act gives the court discretion as to whether or not to stay an action brought in violation of an arbitration clause, ${ }^{100}$ and the same discretion should, it would seem, exist with regard to the specific performance of arbitration agreements. In many cases, specific enforcement of such agreements is unquestionably proper, but in others the balance of convenience may well tip the other way; substantial justice will be better attained, not by compelling the courts specifically to enforce all agreements to arbitrate, but by authorizing them to enforce such an agreement "if the court . . . [thinks] it a proper case for its being so enforced". ${ }^{101}$

It may be objected that to give the courts discretion to grant or refuse specific performance of contracts to arbitrate in the light of the circumstances of each particular case would be to introduce a capricious and unpredictable factor into the law. But there are two answers to this objection: (I) The discretion which would thus be vested in the courts would not be an arbitrary individual discretion, but a judicial discretion to be exercised in accordance with well settled principles. ${ }^{102}$ (2) Courts of equity have long exercised this discretion in granting or refusing specific relief in other classes of cases, without any such unfortunate results. The standards of judicial discretion in specific performance cases have been developed and applied in thousands of decisions; the necessary adherence of the courts to those standards in cases where specific enforcement of arbitration contracts is sought will prevent capriciousness and unpredictability. On the other hand, such a discretion must be preserved to the courts if a system involving compulsory arbitrations is to operate satisfactorily. If arbitration is to be compelled in every instance even though it is unjust in the particular case to hold the party who is compelled to arbitrate to the letter of his bond, the whole arbitral scheme may well be brought into disrepute. And there can be no doubt that such cases of injustice can and do arise. For example, it has become the practice of some business organizations to insert, in standardized "take-it-or-leave-it" contracts, onerous arbitration clauses, frequently coupled with "provisions no court would enforce but which arbitrators invariably do". ${ }^{103}$ Unless, as has been suggested, ${ }^{104}$ it is to be provided by statute that "no party to an arbitration shall be entitled to rely, against the wishes of his

99. Cardozo, C. J., in Matter of Berkovitz v. Arbib \& Houlberg, 230 N. Y. 26I, 274, 130 N. E. 288, 29 I (I92I). Cf. Note (1934) $47 \mathrm{HARv}$. L. Rev. 1036, 1040-1042. As an original question of statutory interpretation, it may well be doubted whether such a construction, even of statutes of the New York and Draft Act type, is a necessary one.

100. See Bristol Corp. v. John Aird \& Co., [I913] A. C. 24I, 257. Cf. Metropolitan

Tunnel \& Public Works, Ltd. v. London Electric Ry., [1926] Ch. 37I, 388-390.

roI. Lord Moulton in Bristol Corp. v. John Aird \& Co., [I913] A. C. 24I, 257.

I02. See Note on Discretion in Granting Specific Performance. 2 CHAFEe AND SIMrson, op. cit. supra note 93, 1270-1271.

103. Phillips, supra note 56, at I274.

104. Nordon, Arbitration (I926) I62 L. T. 262. 
opponent, on an arbitration clause upon which the former insists as part of the standard contract on which he transacts business", the question of whether it is fair and equitable to enforce such a clause in each particular case should at least be left to the judicial discretion of the courts, guided by the standards developed in the long line of equity decisions involving attempts specifically to enforce improvident and unfair contracts against defendants who will suffer hardship if specific relief is granted. ${ }^{105}$ Similarly, where arbitration becomes inequitable by reason of events not anticipated by the parties which occur after the agreement to arbitrate is made, familiar principles are available to guide the courts in deciding whether to compel the parties specifically to perform their agreement, ${ }^{106}$ and justice will be promoted if the courts are permitted to exercise their discretion in accordance with those principles.

In the past, the basic difficulty, in the absence of statute, in the specific enforcement of contracts to arbitrate has lain, as has been pointed out, ${ }^{107}$ in the fact that such contracts were regarded at law as "revocable", so that the authority of arbitrators duly appointed could be revoked so as to prevent an award. This difficulty can be, and in many jurisdictions has been, removed by legislative changes of the common law rule. ${ }^{108}$ The other supposed practical difficulties-inability of the equity court to enforce a decree compelling arbitration, and the like-have been unduly magnified by the courts, ${ }^{109}$ and the effect of the early decisions raising those alleged difficulties can readily be removed by a statutory declaration that a court of equity may, in its judicial discretion, ${ }^{\mathbf{1 1 0}}$ decree specific performance of arbitration contracts, and may, if necessary to make arbitration effective, appoint arbitrators. Such a discretion, wisely exercised, should result in the specific enforcement of contracts to arbitrate where justice will be promoted thereby, and, per contra, would render it unnecessary for the courts, under the guise of construction of arbitration statutes and agreements, to deny specific performance on spurious grounds in order to avoid results regarded by them as unfair. ${ }^{111}$ Whether or not legislation should provide that the proceedings of arbitrators

I05. See 5 PoMeroy, op. cit. supra note $35, \S 22$ I I (improvident contracts) ; Note (1930) 65 A. L. R. 7, 75-77 (collects cases both ways); POAIEROY, Specific Performance (3d ed. I926) § I79 (unfairness). See also Restatenent, Contracts (I932) § 367. Specific performance of a contract may well be denied on such grounds, although the defendant has no case for rescission. See, e. g., Mansfield v. Sherman, 81 Me. 365, 367-368, I7 Atl. 300, 30I302 (I889); Rennyson v. Rozell, I06 Pa. 407, 412 (1884).

106. See Willard v. Tayloe, 8 Wall. 357 (U. S. I869); Pomeroy, Spectfic Performance (3d. ed. I926) $458 \mathrm{n}-459 \mathrm{n}$.

107. See pp. I62-164, supra.

ro8. See supra, p. 164, and notes 53 and 78 .

109. See p. 16I, supra.

IIO. Compare the provision in the SALES ACT $\$ 68$, that a court of equity may, at the suit of the buyer, decree the specific performance of a contract for the sale of a chattel "if it thinks fit". Cf. Hughbanks v. Browning, 9 Ohio App. Ir4, II6 (IgI7).

III. Cf. p. 168, supra; Phillips, supra note 56, at 1272-1278. 
are to be controllable by the courts in matters of law ${ }^{112}$ will depend upon the view taken by the legislature as to the function of arbitration-whether it is regarded as a method of trial or as a substitute for trial. ${ }^{113}$ Assuming that care is exercised in stipulating what disputes are to be submitted to arbitration, and given discretion in the courts to refuse specific performance of contracts to arbitrate where, in the court's opinion, injustice is likely to result, there would seem to be no controlling reason for not permitting the parties, if they so desire, to make arbitrators final judges of matters of law as well as of matters of fact, although a clear and specific expression of such an intention might well be required. Nor does there seem substantial ground, granted these circumstances, for not extending specific performance to arbitration provisions in contracts relating to future disputes thereunder as well as to submissions of existing disputes, ${ }^{114}$ and to appraisals as well as to arbitrations proper. ${ }^{115}$

The future development of the law as to the specific performance of arbitration contracts will proceed largely through legislation. That legislation, if it is to contribute its maximum to the realization of the great potentialities of arbitration as a speedy, friendly, cheap and effective means of settling business controversies, must be drafted with a realistic appreciation of the limitations of the arbitral process and with a recognition of the importance of preserving a margin of judicial discretion in the granting and refusing of specific performance of contracts to arbitrate similar to that which exists with regard to the specific enforcement of other types of contracts.

II2. As, e.g., in England, Massachusetts and the states which have adopted the Uniform Arbitration Act.

II3. See Isaacs, supra note 73.

II4. $C f$. pp. 170, 173, supra.

II5. Cf. note 67 , supra. 